\title{
Simulating soil carbon sequestration from long term fertilizer and manure additions under continuous wheat using the DailyDayCent model
}

\author{
K. Begum $(\mathbb{D} \cdot$ M. Kuhnert $\cdot$ J. Yeluripati $\cdot$ M. Glendining $\cdot$ P. Smith
}

Received: 15 July 2017/Accepted: 6 October 2017/Published online: 16 October 2017

(C) The Author(s) 2017. This article is an open access publication

\begin{abstract}
The widely used ecosystem model DailyDayCent (DDC) was used to predict soil organic carbon (SOC) sequestration and yield under different fertilization treatments on a wheat (Triticum aestivum) monoculture on Broadbalk field, Rothamsted, UK. Over a period of about 170 years, the management practices on the test site, which is separated into plots with different treatments of fertilizer and manure application, are well documented. Four treatments consisting of control (no fertilizer), mineral nitrogen (N) fertilizer (MN), farm yard manure (FYM) and a combination of both (FYMN) have been selected for the study. DDC simulated the greatest increases in SOC (three times higher compared to simulation of the control plot) in the FYM plot. Overall a good agreement between modelled and measured yield was obtained (except in control plots). As observed in the experimental plots, the highest yield predicted by
\end{abstract}

K. Begum $(\bowtie) \cdot$ M. Kuhnert · P. Smith

Institute of Biological and Environmental Science,

University of Aberdeen, 23 St Machar Drive,

Aberdeen AB24 3UU, UK

e-mail: r01kb13@abdn.ac.uk;

begumkhadiza77@gmail.com

J. Yeluripati

The James Hutton Institute,

Craigiebuckler, Aberdeen AB15 8QH, UK

M. Glendining

CAS Department, Rothamsted Research, West Common,

Harpenden AL5 2JQ, UK the model is with FYMN plot (more than three times higher relative to the control plot). A sensitivity test for the MN and FYM plots demonstrated that predicted SOC was relatively insensitive (1\%) to bulk density, $\mathrm{pH}$ and field capacity. Higher sensitivity (4-7\%) of predicted SOC changes were observed by changes in external $\mathrm{C}$ input. An increase of temperature by $1{ }^{\circ} \mathrm{C}$ or precipitation by $10 \%$ decreased predicted SOC by $2-4 \%$ and vice versa, and simulated a $1-4 \%$ variability in yield. DDC is a useful tool for simulating SOC in the long term plots, with a good fit to data, and is useful for examining alternate hypotheses of yield and SOC responses.

Keywords Long term experiments · Modelling · SOC $\cdot$ Fertilization $\cdot$ Sensitivity

\section{Introduction}

Soil organic matter (SOM) is an important component in terrestrial ecosystems. Beside its significant role in nutrient availability, soil resilience, water holding capacity and crop productivity (Lal 2013; Smith et al. 1996), SOM plays a key role in mitigating climate change by capturing atmospheric carbon dioxide $\left(\mathrm{CO}_{2}\right)$, an important radiatively active gas emitted mainly by anthropogenic activities (Alexander et al. 2015; Smith et al. 1996). It is estimated that close to 
$90 \%$ of the total mitigation potential in the agricultural sector could be derived from soil organic carbon (SOC) sequestration, with about $10 \%$ from reduction of non- $\mathrm{CO}_{2}$ greenhouse gases (Smith et al. 2007). Several mitigation options have been suggested for croplands, as reviewed in Intergovernmental Panel on Climate Change, IPCC (Smith et al. 2007, 2014) e.g., nutrient management, tillage and residue management, and water management. As a consequence, article 3.4 of the Kyoto Protocol includes agricultural management practices as a potential carbon (C) sink to mitigate climate change impact (Smith 2004), and many Nationally Determined Contributions submitted by parties to the United Nations Framework Convention on Climate Change, as part of the Paris Climate Agreement, also include soil C sequestration.

Changes in SOC content can be very slow; sometimes taking more than 100 years to reach a new equilibrium, depending on the type of management practices and soil type (Smith et al. 1996). Therefore, existing long-term datasets may be the best options to assess whether current agronomic practices are sustaining agricultural and environmental quality. The complexity of soil $\mathrm{C}$ dynamics, and slow changes of SOC, mean that computer models are a powerful option for simulating and predicting SOC change in different fertilization experiments over long time scales (Powlson 1996). The Broadbalk winter wheat experiment at Rothamsted is the oldest continuing agronomic field experiment in the world (Rothamsted Research 2006). To predict SOC dynamics, the RothC model was tested at this site (Jenkinson et al. 1990). Powlson et al. (2012) recently presented SOC changes with RothC at this site, and Falloon and Smith (2000) studied SOM turnover using RothC and CENTURY. The above literature, however, is restricted to the investigation of SOC changes only. Several studies have been published on testing the impact of different fertilization regimes on yield at Broadbalk and observed weather has direct (Chmielewski and Potts 1995) or indirect impact (Thorne et al. 1988) on yield variability. Recently, Powlson et al. (2014) investigated the reason for comparatively lower yield in continuous wheat section relative to wheat rotation, and found impacts of 'adverse' weather, which sometimes leads to very late sowing due to saturation of the soil when the original planting time was planned, or susceptibility to disease of the wheat variety used.
SOC changes and yield have been studied separately in a few previous studies, but they have not been evaluated together. To support holistic policy, tools that allow soil $\mathrm{C}$ change and yield to be considered together are needed. The performance of ecosystem models that can determine the impact of the different processes on soil $\mathrm{C}$ dynamics and plant production using available data is therefore critical. The current study aimed to predict SOC sequestration and yield under long term fertilization treatments at the Broadbalk continuous wheat experiment using the widely used ecosystem model DailyDayCent (DDC). DDC has recently been used to simulate nitrous oxide fluxes from wheat cropland in the UK (Fitton et al. 2014) and from a corn-wheat-barley rotation in France (Senapati et al. 2016). The magnitude of SOC sequestration depends on a number of factors including variables describing weather, soil properties, management and external nutrient input. A sensitivity analysis was used to detect the most sensitive parameters, which is crucial for a better understanding of the processes and aspects of the model structure critical in simulating yield and SOC change. A better understanding of the parameter sensitivity will also improve the analysis for future model experiments.

\section{Methods}

\section{Site description}

The study uses data from the Broadbalk continuous wheat experiment, situated at Rothamsted Research, Harpenden, Herts UK $\left(0^{\circ} 22^{\prime} \mathrm{W}\right.$ and $51^{\circ} 49^{\prime} \mathrm{N}, 128 \mathrm{~m}$ above sea level). Initially the experiment was set up to test the effects of various combinations of fertilizers on crop yield, but over time the experiment has been modified, to ensure that it remains relevant to current agricultural issues, whilst retaining its long-term integrity (Macdonald et al. 2015). The fertilizer treatments varied at the initiation of the experiment, but in 1852 a scheme was established which has continued, with some modifications, to the present day. Originally, the treatments were applied to single plots, about $320 \mathrm{~m} \mathrm{(m)} \mathrm{long} \mathrm{and} 6 \mathrm{~m}$ wide (Moss et al. 2004). In 1926 the field was sub-divided into five sections, crossing the treatment strips, which were sequentially fallowed to control weeds. In 1968 the experiment was further divided into 10 sections, so 
Table 1 Different nitrogen fertilizer and manure treatments applied to the plots selected for the current study

\begin{tabular}{ll}
\hline Name of the plot & Treatment \\
\hline Control & No fertilizer or manure since 1843 \\
MN & $144 \mathrm{~kg} \mathrm{Nha}^{-1} \mathrm{a}^{-1}$ since $1843^{\mathrm{a}}$ \\
FYM & $35 \mathrm{t} \mathrm{ha}^{-1} \mathrm{a}^{-1} \mathrm{FYM}$ since $1843^{\mathrm{b}}$ \\
FYMN & $35 \mathrm{t} \mathrm{ha}^{-1} \mathrm{a}^{-1} \mathrm{FYM}$ since $1885^{\mathrm{b}} ;$ \\
& Plus 96 and $144 \mathrm{~kg} \mathrm{~N} \mathrm{ha}^{-1}$ added along with FYM since 1968 and 2005, respectively
\end{tabular}

${ }^{\mathrm{a}}$ For this study this treatment is considered as $\mathrm{N}$ fertilizer only, the plot has also received non-limiting $\mathrm{P}, \mathrm{K}, \mathrm{Mg}$ and $\mathrm{Na}$ since 1843

${ }^{\mathrm{b}} \mathrm{C}$ content in FYM (farmyard manure) estimated as $3 \mathrm{t} \mathrm{ha}^{-1}$, total $\mathrm{N}$ content estimated before 1968 as $224 \mathrm{~kg} \mathrm{~N} \mathrm{ha}^{-1}$ (Johnston and Garner 1969) and measured thereafter between 158 and $322 \mathrm{~kg} \mathrm{~N} \mathrm{ha}^{-1}$

that the yield of continuous wheat could be compared with wheat grown in rotation. Modern, short-straw cultivars were introduced. The plots are now approximately $25 \mathrm{~m}$ long and $6 \mathrm{~m}$ wide (Moss et al. 2004). The management practices on the test site are well documented.

The present study uses data from Section one, where winter wheat has been grown continuously since 1843, with occasional fallow years to control weeds, the last in 1966. The crop is sown in the autumn (usually September-October) and harvested in the summer (usually August) of the following year. The soil is clay loam (Soil Survey of England and Wales classification, Avery 1980), alkaline in nature $(\mathrm{pH}$ between 7.1 and 8.2). The average temperature is $9{ }^{\circ} \mathrm{C}$, and the average annual precipitation is about $700 \mathrm{~mm}$. In order to test the optimum yield, the management practices have been changed from time to time. Weed control was one of the major concerns on the site and weeds were removed manually until 1926, then by sequential fallowing, 1 year in five from 1926 to 1966 . Herbicides were introduced to control weeds in 1964 (Moss et al. 2004). The combination of modern higher yielding varieties, better weed control, liming and the use of fungicides increased yields by 2-3 times in all fertilized treatments.

The straw is removed at harvest in this section, and we assume residue incorporation of $38 \%$ of total above-ground residue (consisting of stubble and chaff and uncollected straw) for the control treatment, and $30 \%$ for the other fertilized treatments in this continuous wheat section as suggested by previous literature (Powlson et al. 1986). For more details of the site and the treatments see http://www.era.rothamsted.ac.uk/ Broadbalk.

In order to estimate the SOC trend by the model simulations in this study, four plots were selected with different fertilization treatments. Beside a no fertilizer or manure plot (Control), three plots with different nutrient applications were considered: mineral nitrogen $(\mathrm{N})$ fertilizer $(\mathrm{MN})$, farm yard manure (FYM) and combined application of mineral $\mathrm{N}$ and manure (FYMN). All details are summarized in Table 1.

\section{SOC data}

There are 11-14 measurements of SOC between 1843 and 2014, measured at irregular intervals (5-25 years). The initial SOC content for all plots in 1843 was estimated to be $1 \%$ in the top $0.23 \mathrm{~m}$. SOC stock $\left(\mathrm{t} \mathrm{ha}^{-1}\right)$ at $0.23 \mathrm{~m}$ depth was obtained from e-RA, the electronic Rothamsted Archive e-RA (http://www.era.rothamsted.ac.uk/Broadbalk/bbk_ open_access). SOC $\left(\mathrm{t} \mathrm{ha}^{-1}\right)$ was estimated from measured \%SOC, standard soil weights, and adjustment for changes in bulk density (BD) in the FYM and FYMN treatments. As the model provides SOC outputs for $0.20 \mathrm{~m}$ depth, the modelled SOC was recalculated for a $0.23 \mathrm{~m}$ depth based on the assumption of an equal distribution of SOC in the top layer, so modelled values were divided by 0.87 .

\section{Yield data}

Grain and straw yield data were obtained from e-RA (http://www.era.rothamsted.ac.uk/). We used annual grain yields from 1852 to 2014 for the four treatments indicated in Table 1 (1885-2014 for FYMN). There were 10 fallow years (no yield) between 1926 and 1966, so a total of 153 years of data (120 years for FYMN). Actual agronomic data (sowing and harvest dates, dates of fertilizer and manure application etc.) were also provided in the data base. Nitrogen content 
data of the FYM applied was available from 1968 onwards; before that date total $\mathrm{N}$ content was estimated (Table 1).

\section{Model description and initialization}

DDC (version from 1st of May 2013) was derived from the model CENTURY (Parton et al. 1998) and DayCent (Del Grosso et al. 2001, 2012). The DDC includes a daily plant production sub-model at a daily time step. This modification allows DDC to produce daily plant production outputs like net primary productivity, net ecosystem exchange and heterotrophic respiration which are directly comparable with daily eddy covariance measurements, whereas DayCent model version computes these variables on a weekly basis. DDC simulates the biogeochemical processes of $\mathrm{C}, \mathrm{N}$, phosphorus, and sulphur cycling associated with SOM dynamics for grasslands, agricultural lands, forests, and savannas. The minimum weather data used to run the model are precipitation, maximum and minimum temperature at daily time steps. Required input data include (1) soil data such as soil texture, soil depth, BD, water characteristics like field capacity (FC), hydraulic conductivity and water filled pore space for each depth specified by the model (2) agronomic information of the test sites, such as sowing date, harvesting date, ploughing events (date and procedure), fertilization events (date, kind and amount of fertilizer), irrigation events (date and amount) and residue removal, and (3) phenological parameters and plant specific constants describing the growth potential and sensitivity to drought or nutrient stress (Del Grosso et al. 2012).

Sub-models in DDC determine soil organic matter (SOM) decomposition, nitrification and denitrification, plant production and soil water dynamics. Figure 1a represents the plant production sub model. In the plant production sub model, the assimilated $\mathrm{C}$ is allocated to aboveground and belowground biomass pools by allocation factors which are affected by nutrient and water stress. $\mathrm{C}$ from plant residues and animal manure is subdivided into structural and metabolic pools on the basis of lignin fraction (Fig. 1b). The metabolic pool contains readily decomposable materials (turn-over time 0.1-1 year), whereas the structural pool contains plant lignin that is resistant to decomposition (turn-over time 1-5 year). The SOM sub model transfers $\mathrm{C}$ to three SOC pools, namely active (turn-over time 1-5 year), slow (turn-over time 20-50 years) and passive pools (turn-over time 200-1500 years), where the turnover of $\mathrm{C}$ in different pools is described by a first order kinetic considering decomposition rate, soil texture, soil temperature, moisture, tillage and lignin/ $\mathrm{N}$ ratio (Parton 1996).

The overall set up for the simulations to establish initial steady state conditions for the different SOC pools at the start of the experiment are: (1) initialization starts with grass for 1500 years followed by arable cropping of a further 350 years (as the literature suggested; Avery and Bullock 1969; Rothamsted Research 2006), with the minimum inorganic fertilizer $\left(50 \mathrm{~kg} \mathrm{~N} \mathrm{ha}^{-1}\right)$ application and keeping minimum residues $(1 \%)$ left in the field, (2) the simulation followed the actual management practices since 1843 , the beginning of the experiment (details were described in Table 1). Annual inputs are roots, roots exudates, stubble and part of the chaff (estimated by Jenkinson et al. 1992). In the model the belowground biomass is simulated and dead roots contribute to the carbon pools, (3) to better reflect improved cultivars and thereby represent the higher yield observed since 1968, we adjusted the plant production parameter in the DDC crop file, and the value remained fixed during 1968-2014. No irrigation is applied to the Broadbalk experiment.

Statistical methods

Performance of the DDC model was tested using the model evaluation statistical routines provided in MODEVAL (as suggested by Smith et al. 1997; Smith and Smith 2007). We compared the measured and modelled SOC and yield by calculating root mean square error (RMSE), mean error (E), mean difference between observation and simulation $(\mathrm{M})$, and sample correlation coefficient (r), shown below as Eqs. 1, 2, 3 and 4, respectively:

$$
\begin{aligned}
& R M S E=\frac{100}{\bar{O}} \sqrt{\frac{\sum_{i=1}^{n}\left(P_{i}-O_{i}\right)^{2}}{n}} \\
& E=\frac{100}{\bar{O}} \frac{\sum_{i=1}^{n}\left(O_{i}-P_{i}\right)}{n} \\
& M=\frac{\sum_{i=1}^{n}\left(O_{i}-P_{i}\right)}{n}
\end{aligned}
$$


Fig. 1 Schematic structure of a the plant production sub-model and $\mathbf{b}$ the SOC sub-model in DDC (Adapted from Parton and Rasmussen 1994; Paustian et al. 1997) (a)
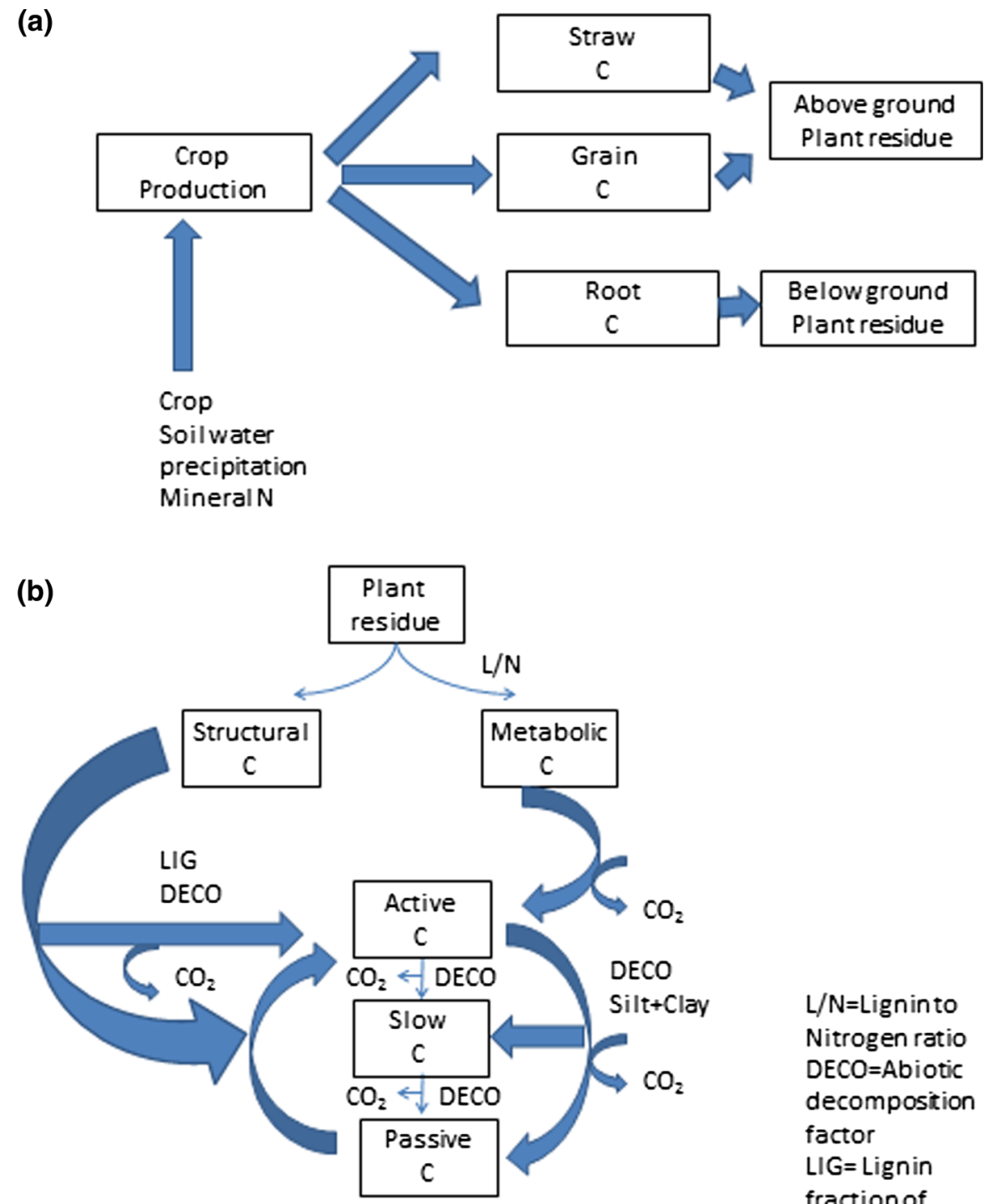

$\mathrm{L} / \mathrm{N}=$ Lignin to Nitrogen ratio DECO=Abiotic decomposition factor LIG= Lignin fraction of structural material

$$
r=\frac{\sum_{i=1}^{n}\left(O_{i}-\bar{O}\right)\left(P_{i}-\bar{P}\right)}{\sqrt{\left[\sum_{i=1}^{n}\left(O_{i}-\bar{O}\right)^{2}\right]} \sqrt{\left[\sum_{i=1}^{n}\left(P_{i}-\bar{P}\right)^{2}\right]}}
$$

where $\bar{O}$ and $\bar{P}$ is the mean values of observed and predicted data and $O_{i}$ and $P_{i}$ indicate the observed and predicted values, respectively, and $\mathrm{n}$ is the number of measurements. The significance of $r$ and $M$ was tested using an F-test (at probability levels of $p=0.05$, $p=0.01$ and $p=0.001$ ), and Student's two-tailed $t$ test (critical at $2.5 \%$ ), respectively.

\section{Sensitivity test}

The sensitivity of the simulated SOC and yield towards several input parameters were tested by the modification of 10 parameters (one parameter at a time) including 2 climatic parameters (daily temperature and precipitation), 4 soil parameters (FC, BD, $\mathrm{pH}$ and clay content), initial SOC content, and 3 additional management inputs (residue return, $\mathrm{N}$ content of fertilizer in MN plot and C content of the FYM in FYM plot). Based on the assessment of Senapati et al. 
(2016), the range used in this study were considered as daily air temperature modified by $\pm 1{ }^{\circ} \mathrm{C}, \mathrm{pH}$ by \pm 1 unit, and the other parameters by $\pm 10 \%$ of the measured values (baseline values). For each simulation, only a single input was varied and all other parameters remained the same as in baseline level. The simulated final SOC in response to a change of individual parameters for the period of 1843-2014 was deducted from the final simulation with baseline SOC for the same period, and the percentage change in SOC due to change in each input was determined. Average values for the period 1968-2014 were calculated to assess sensitivity of yield to different parameters.

\section{Results}

SOC and yield simulation

The modelled SOC showed a good fit with the measured data (Fig. 2), which is supported by a low values (RMSE $<10 \%$ ) in the error analysis (Table 2 ).

SOC in the control plot shows a slight negative trend at the end of the period which is reflected in the modelled results $(\mathrm{r}=0.54)$, with slight underestimation $(\mathrm{E}=1 \%)$ but no bias. There is a small systematic bias (slight overestimation, $\mathrm{E}=-5 \%$ ) in the $\mathrm{MN}$ plot, and the positive relationship $(r=0.48)$ between modelled and measured SOC is not significant. Modelled SOC in the FYM and FYMN plots shows a highly significant agreement $(p=<0.001)$ with the measurements. The decrease of SOC at the end of the simulations tends to underestimate SOC in FYM plot, but with no significant bias. As seen in the measurements, the maximum SOC was simulated for the FYM plot, more than three times greater than the control plot, and two times greater than the $\mathrm{MN}$ plot. The second highest impact was observed by application of $\mathrm{N}$ and manure (FYMN plot, started in 1885). Simulated output and measured SOC increased rapidly over the first 80 years, after which SOC increase rate slowed.

The modelled yield in general shows a good fit with the measured data (RMSE $<45 \%$ ) except for simulation of the control plot, which is underestimated by $70 \%$ or $0.66 \mathrm{tha}^{-1}$ (Fig. 3 and Table 2). The yield under different fertilization shows a highly significant positive relationship $(p<0.001)$. The highest yield was seen in the FYMN plot, with an average of $6 \mathrm{tha}^{-1}$ for the period of 1968-2014, which was well matched by the model (Fig. 3). The average observed and modelled yield for the MN and FYMN plots are the same, at around $5 \mathrm{tha}^{-1}$. A systematic bias (overestimation by less than $1 \mathrm{tha}^{-1}$ ) was observed in the $\mathrm{MN}$ and FYMN plots.

Sensitivity analysis

Sensitivity of simulated SOC to the tested parameters on both plots showed that the maximum change in SOC over 170 years was about $8 \%$ different from baseline inputs, and the impact appeared to be lower due to changes in soil properties (FC, BD and soil $\mathrm{pH}$ ) observed in both plots (Table 3 ). Changes of $\mathrm{N}$ content in mineral fertilizers has negligible impact on SOC increase, as observed in the MN plot, whereas changes of $\mathrm{C}$ content in manure by $10 \%$ lead to changes in SOC by $4-7 \%$, with the maximum impact obtained in the FYM plot among the selected parameters. Increasing air temperature by $1{ }^{\circ} \mathrm{C}$ tends to decrease SOC by $2-4 \%$, while SOC increases by $3-5 \%$ with decreasing temperature. There was a $3-4 \%$ change in SOC when precipitation was modified by $10 \%$. Yield changed by a maximum of $8 \%$ on modification of the selected parameters. Yield is less responsive to changes of temperature by $1{ }^{\circ} \mathrm{C}$ than SOC and the response was lower $(1 \%)$ in the MN plot than the plot with FYM application. Yield declined by $1-2 \%$ on the MN plot when increasing or decreasing precipitation by $10 \%$. Increased precipitation increase yield by $3 \%$ on the FYM plot, while yield decreased by $4 \%$ on lowering precipitation on this plot. Yield changes of around $8 \%$ under modification of FC indicates that the model is sensitive to these parameters. A yield decline of 3-4\% occurred under an increase of clay content by $10 \%$ and vice versa. A $10 \%$ decrease of $\mathrm{N}$ content in chemical fertilizer reduced yield by $5 \%$, and a $6 \%$ higher yield was obtained when the $\mathrm{C}$ content in manure was increased by $10 \%$ compared to the current practice. As for the SOC content, $\mathrm{BD}$ and $\mathrm{pH}$ had a negligible impact $(0.02-2 \%)$ on yield over the 170 years.

\section{Discussion}

Modelled SOC and yield

Testing the DDC model for its ability to simulate SOC indicates a good agreement between modelled and 
(a) Control plot

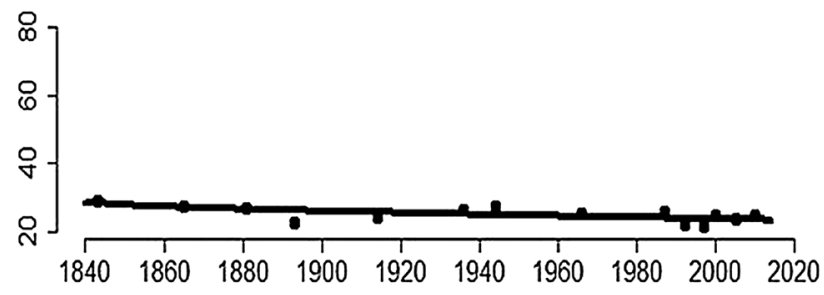

(b) MN plot

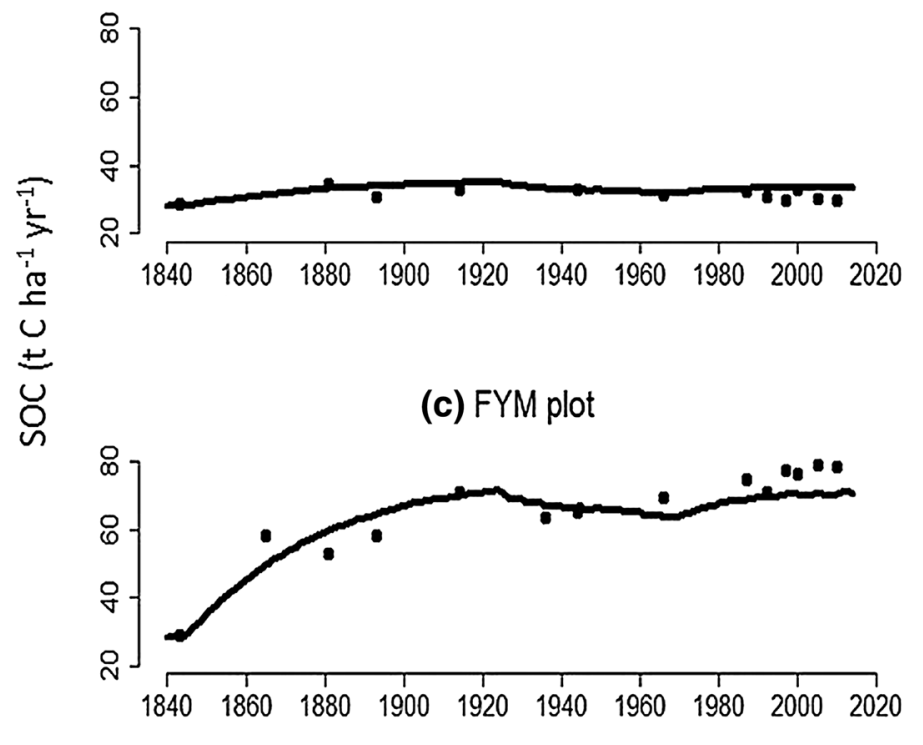

(d) FYMN plot

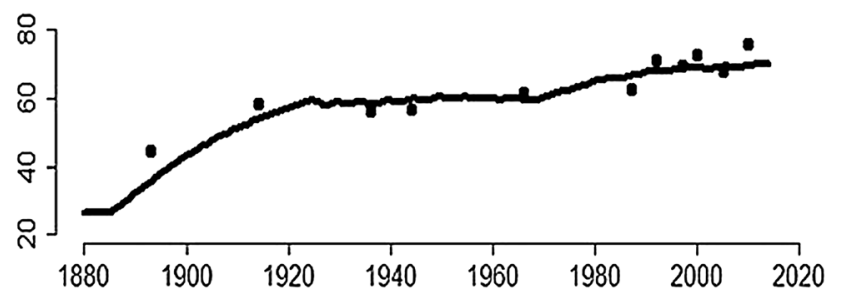

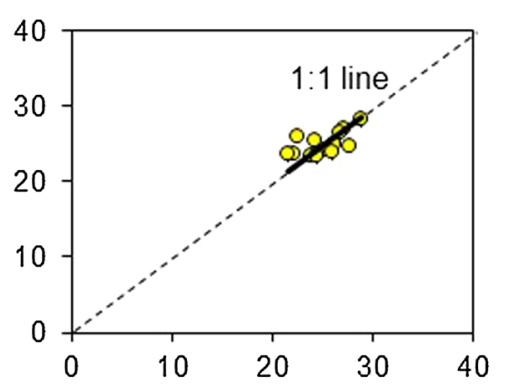
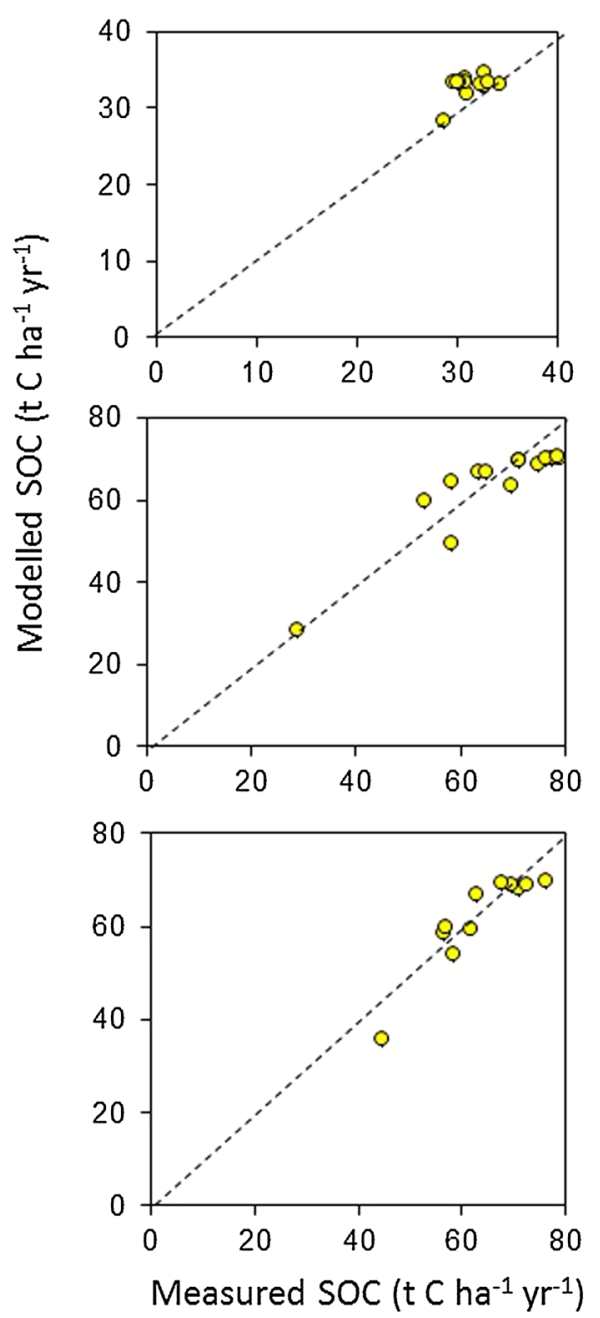

Fig. 2 Measured (points) and modelled (line) SOC for the different treatments $(0-0.23 \mathrm{~m}$ depth $)$ in the long term Broadbalk continuous wheat test site for the period

measured values on the considered sites over the studied period. As seen in the measurements, lower SOC contents were simulated in the control plot, since inputs of $\mathrm{C}$ were lowest on this low yielding plot. On the MN plot, SOC increased by $20 \%$ more than in the
1843-2014 (the FYMN treatment started in 1885): a control plot b MN plot, c FYM plot and d FYMN plot

control plot, due to residue $\mathrm{C}$ input (Glendining et al. 1996). The uptake of $C$ by grain and straw at harvest simulated by DDC is $3.53 \mathrm{t} \mathrm{Cha}^{-1} \mathrm{a}^{-1}$ for the period 1970-1985, which is close to the value of $3.51 \mathrm{t} \mathrm{Cha}^{-1} \mathrm{a}^{-1}$ estimated by Jenkinson et al. 
Table 2 Statistical output for modelled and measured SOC (1843-2014) and yield (1852-2014) under different fertilization treatment from the Broadbalk continuous wheat experiment

\begin{tabular}{|c|c|c|c|c|}
\hline & $\begin{array}{l}\text { Control } \\
\left(\mathrm{n} 1=14^{\mathrm{a}}\right. \\
\left.\mathrm{n} 2=153^{\mathrm{b}}\right)\end{array}$ & $\begin{array}{l}\mathrm{MN} \\
(\mathrm{n} 1=12 \\
\mathrm{n} 2=153)\end{array}$ & $\begin{array}{l}\text { FYM } \\
(\mathrm{n} 1=14 \\
\mathrm{n} 2=153)\end{array}$ & $\begin{array}{l}\text { FYMN } \\
(\mathrm{n} 1=11 \\
\mathrm{n} 2=120)\end{array}$ \\
\hline \multicolumn{5}{|l|}{ SOC } \\
\hline RMSE (\%) & 6.59 & 7.12 & 8.88 & 6.65 \\
\hline $\mathrm{E}(\%)$ & 1.06 & -5.01 & 3.88 & 2.74 \\
\hline $\mathrm{M}\left(\mathrm{t} \mathrm{ha} \mathrm{a}^{-1}\right)$ & $0.08^{\mathrm{ns}}$ & $-1.57 *$ & $2.56^{\mathrm{ns}}$ & $1.69^{\mathrm{ns}}$ \\
\hline $\mathrm{r}$ & $0.61 *$ & $0.48^{\mathrm{ns}}$ & $0.87 * * *$ & $0.92 * * *$ \\
\hline \multicolumn{5}{|l|}{ Yield } \\
\hline RMSE $(\%)$ & 83.35 & 41.72 & 38.00 & 32.01 \\
\hline $\mathrm{E}(\%)$ & 71.17 & -2.62 & -4.21 & -6.55 \\
\hline $\mathrm{M}\left(\mathrm{t} \mathrm{ha} \mathrm{a}^{-1}\right)$ & $0.66^{*}$ & $-0.08 *$ & $-0.16^{\mathrm{ns}}$ & $-0.23^{*}$ \\
\hline $\mathrm{r}$ & $-0.24 * *$ & $0.79 * * *$ & $0.75 * * *$ & $0.68 * * *$ \\
\hline
\end{tabular}

$n s$ non-significant

${ }^{\mathrm{a}} \mathrm{n} 1=$ number of samples of measured SOC

${ }^{\mathrm{b}} \mathrm{n}=$ number of samples of measured yield

* Significant correlation (r) between modelled and measured at $p<0.05$, or significant mean error $(\mathrm{M})$ at $p=0.025$

** Significant correlation (r) between modelled and measured at $p<0.01$

*** Significant correlation ( $\mathrm{r}$ ) between modelled and measured at $p<0.001$

(1992) for the MN plot. DDC estimates C input in the $\mathrm{MN}$ plot quite well. However, a slight over prediction of SOC at the end of simulation was observed. The greater $\mathrm{C}$ input due to higher yield tends to accumulate more $\mathrm{C}$ in the soil, thereby leading to an over prediction of SOC in the MN plot. As for the measurements, a sharp increase in SOC occurred in the middle years of the simulations of the manured plot, which was attributed to accumulation of more $\mathrm{C}$ in SOC slow pool. In the FYMN plot, direct $\mathrm{C}$ addition by manure and residue input outweighed the soil respiration over the study period. In contrast to the observations, a slower SOC increase was simulated in the FYM plot, which suggests that the reduced manure-only applications during the fallow period could not compensate for the $\mathrm{C}$ lost by respiration.

Overall, a good agreement was observed between modelled and measured yield, except for the plot with no nutrient input (control plot). In spite of no fertilizer application, a yield increase in the control plot has been observed (Clark et al. 2012; Powlson et al. 2014), which, it has been proposed, could be due to atmospheric $\mathrm{N}$ deposition of around $35-45 \mathrm{~kg} \mathrm{~N}^{-1} \mathrm{a}^{-1}$. Including $\mathrm{N}$ deposition in
DDC tends to reduce the gap between modelled and measured yield, but could not explain the entire gap between modelled results and observations. DDC was originally developed for grasslands (Parton et al. 1987) and croplands where there is usually an external $\mathrm{N}$ source, and biogeochemical models are known to simulate low input regimes less well (Senapati et al. 2016). It could also be that the model does not simulate enough mineralization of organic matter to release $\mathrm{N}$ for use by the crops.

Sensitivity analysis

The sensitivity test revealed that SOC at the Broadbalk site was less sensitive to changes of soil BD and FC by $10 \%$ and $\mathrm{pH}$ by 1 unit. Since BD cannot be altered during model simulations, for the FYM and FYMN plots we used the initial soil weight value of $2.88 \times 10^{6} \mathrm{~kg} \mathrm{ha}^{-1}$ at $0-0.23 \mathrm{~m}$ as estimated in 1843 for the duration of the simulations, though soil weight is known to have decreased over time to $2.52 \times 10^{6} \mathrm{~kg} \mathrm{ha}^{-1}$ at $0-0.23 \mathrm{~m}$ measured in 2000 . However, our sensitivity analysis has shown that SOC change is relatively insensitive to changes in $\mathrm{BD}$, with 
(a) Control plot

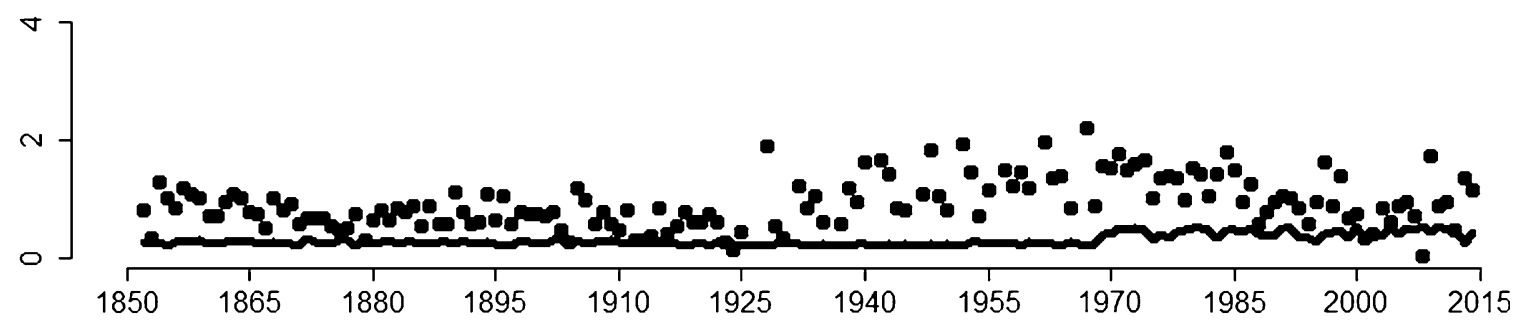

(b) MN plot
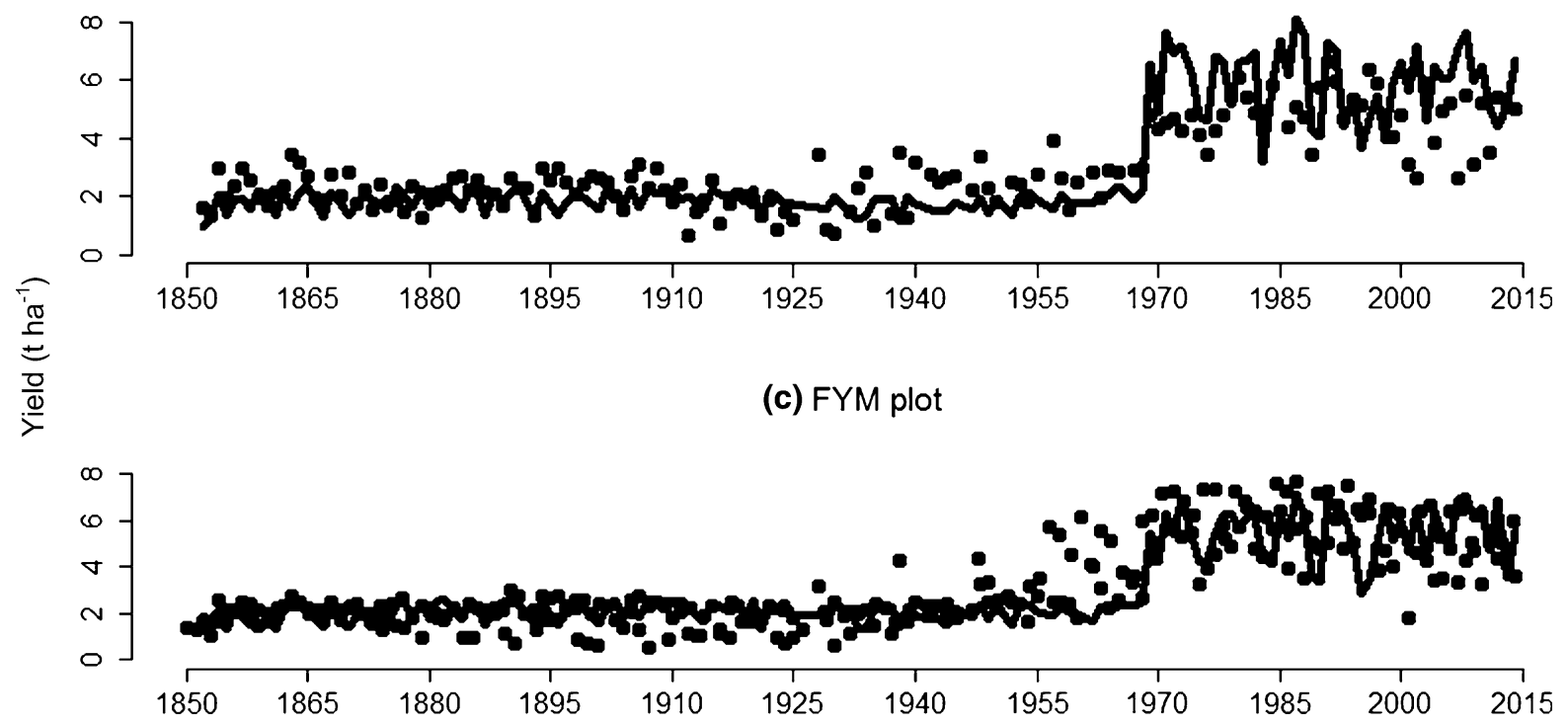

(d) FYMN plot

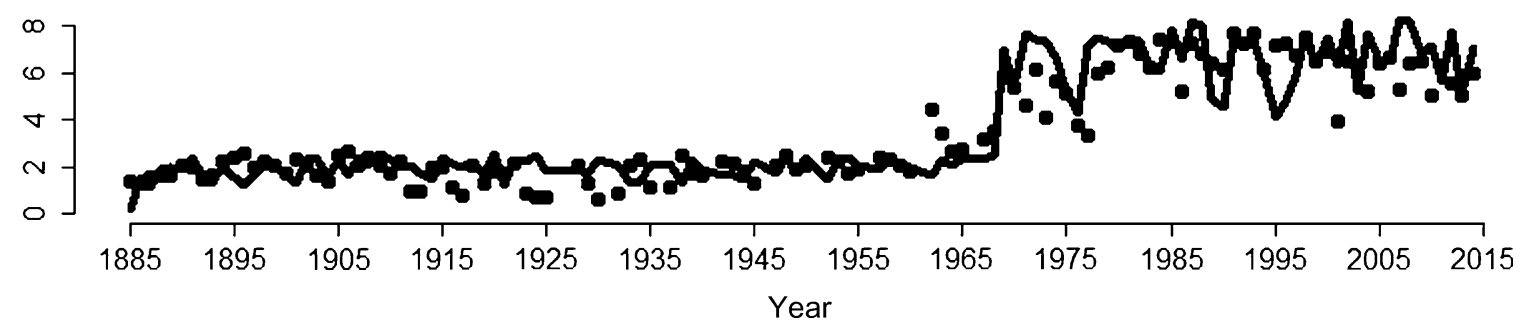

Fig. 3 Modelled (line) and measured (point) yield under four treatments in the Broadbalk continuous winter wheat experiment test site for the period of 1852-2014 (FYMN treatment

a $10 \%$ decrease in BD leading to only a $0.28 \%$ decrease in SOC, so using a fixed BD value would not have greatly affected the simulation outcomes. Similarly, lime has been applied in some plots to keep $\mathrm{pH}$ between 6.5 and 8.2 on this site. We tested the sensitivity to $\mathrm{pH}$, and the model experiment revealed started in 1885). a Control plot, b MN plot, c FYM plot and d FYMN plot. Note that the $y$-axis scale range for $\mathbf{a}$ is $0-4 \mathrm{t} \mathrm{ha}^{-1}$ while for the other treatment $0-8 \mathrm{tha}^{-1}$

that $\mathrm{SOC}$ is relatively insensitive to a change in $\mathrm{pH}$ by one unit, which may be too small to impact on plant production or microbial activity. An additional model experiment of reducing $\mathrm{pH}$ by 2 units shows an increase in the SOC pool by $5 \%$ and an $8 \%$ increase in yield compared to the original simulations. It should 
Table 3 Sensitivity of modelled SOC (1843-2014) and yield (1968-2014) to climatic parameters, soil properties, model variables and management input on $\mathrm{MN}$ and FYM plot

\begin{tabular}{|c|c|c|c|c|}
\hline Simulated variables & Parameter & Range & $\begin{array}{l}\text { MN plot } \\
\% \text { change }\end{array}$ & $\begin{array}{l}\text { FYM plot } \\
\% \text { change }\end{array}$ \\
\hline \multicolumn{5}{|l|}{ SOC } \\
\hline & Daily air temperature & $\pm 1{ }^{\circ} \mathrm{C}$ & $-2.15 / 2.56$ & $-4.24 / 5.03$ \\
\hline & Daily precipitation & $\pm 10 \%$ & $-3.15 / 4.47$ & $-3.13 / 4.19$ \\
\hline & $\mathrm{FC}$ & $\pm 10 \%$ & $0.65 /-0.94$ & $-0.21 /-0.16$ \\
\hline & $\mathrm{BD}$ & $\pm 10 \%$ & $-0.1 / 0.1$ & $0.16 /-0.28$ \\
\hline & $\mathrm{pH}$ & \pm 1 & $-0.26 / 0.75$ & $-0.10 / 1.2$ \\
\hline & Clay content & $\pm 10 \%$ & $-1.06 / 2.71$ & $-1.39 / 2.58$ \\
\hline & Initial SOC & $\pm 10 \%$ & $6.33 /-7.95$ & $3.07 /-3.84$ \\
\hline & Residue return & $\pm 10 \%$ & $6.66 /-6.48$ & $3.77 /-3.66$ \\
\hline & $\mathrm{N}$ content in fertilizer & $\pm 10 \%$ & $0.23 /-0.66$ & \\
\hline & $\mathrm{C}$ content in manure & $\pm 10 \%$ & & $4.0 /-7.25$ \\
\hline \multicolumn{5}{|l|}{ Yield } \\
\hline & Daily air temperature & $\pm 1{ }^{\circ} \mathrm{C}$ & $-1.06 /-0.98$ & $-2.20 / 2.46$ \\
\hline & Daily precipitation & $\pm 10 \%$ & $-1.15 /-1.92$ & $2.67 /-4.26$ \\
\hline & $\mathrm{FC}$ & $\pm 10 \%$ & $6.69 /-7.75$ & $6.58 /-7.58$ \\
\hline & $\mathrm{BD}$ & $\pm 10 \%$ & $-0.14 /-0.13$ & $2.03 /-2.38$ \\
\hline & $\mathrm{pH}$ & \pm 1 & $-0.10 / 0.23$ & $-0.02 / 1.64$ \\
\hline & Clay content & $\pm 10 \%$ & $-3.43 / 4.65$ & $-3.56 / 3.77$ \\
\hline & Initial SOC & $\pm 10 \%$ & $0.06 /-0.07$ & $0.07 /-0.08$ \\
\hline & Residue return & $\pm 10 \%$ & $0.86 /-0.89$ & $2.12 /-2.15$ \\
\hline & $\mathrm{N}$ content in fertilizer & $\pm 10 \%$ & $1.64 /-5.01$ & \\
\hline & $\mathrm{C}$ content in manure & $\pm 10 \%$ & & $5.88 /-4.81$ \\
\hline
\end{tabular}

be noted, however, that reduced $\mathrm{pH}$ will have other, detrimental effects on the soil, which will have an effect on crop growth. Decreasing clay content increases simulated SOC and plant production. The sensitivity tests of modified $\mathrm{C}$ applications show that external $\mathrm{C}$ input is one of the most important factors affecting SOC change that is reflected in both the MN and the FYM plots. Addition of $10 \%$ more residue increased $\mathrm{C}$ input to the soil and so enhanced SOC. SOC increased further when manure was applied, as observed in the FYM plot. Our findings are in line with Oliveira et al. (2017) who predicted the impact of SOC changes under different external $\mathrm{C}$ sources using the DayCent model on a Brazilian sugarcane crop. Their study suggests that the negative impact of SOC due to residue removal $(75 \%)$ can be compensated for by manure application. Although a $10 \%$ increase of initial SOC tends to increase SOC, the effect was greater in the MN plot than the plot with FYM applications, but the trend of SOC change was the same as with baseline initial SOC content. This suggests that in terms of SOC change, the impact of initial SOC is negligible. Model results suggest that changes in rainfall of only $10 \%$ on this site do not change the soil water status.

Among the three fertilization practices, FYM sequestered the most $\mathrm{C}$ but FYMN gave the best crop yield. The FYMN treatment has had smaller organic inputs than the FYM treatment, as the applications of manure started in 1885, 42 years later than the FYM treatment (see Table 1). Based on SOC sequestration and plant growth, the plot with FYMN shows the highest rates of SOC gain. SOC sequestration through this management is estimated to be around $0.3 \mathrm{t} \mathrm{C} \mathrm{ha}^{-1} \mathrm{a}^{-1}$ over a 130 year period, which is at the top end of the range reported by Smith et al. (2008) for SOC sequestration potential for cool moist croplands $\left(0.002-0.30 \mathrm{t} \mathrm{C} \mathrm{ha}^{-1} \mathrm{a}^{-1}\right)$. To put this rate of soil carbon sequestration in context, practicing such management on all arable land in the UK would lead to SOC sequestration of $\sim 2$ Teragram $(\mathrm{Tg}) \mathrm{C} \mathrm{a}^{-1}$ which is about $1.8 \%$ of UK's $\mathrm{CO}_{2}-\mathrm{C}$ emissions of $110 \mathrm{Tg} \mathrm{C} \mathrm{a}^{-1}$ in 2015 (BEIS 2015). However in reality it might not be possible, because increase of SOC by manure addition to one field could result in a 
decrease of SOC in other locations due to less manure being applied there (depending on whether or not the manure was used optimally; Smith et al. 2000). SOC sequestration by manure depends on its applicability and availability. FYM produced in the UK amounted to $35.7 \mathrm{Tg}$ in 2010 (Smith and Williams 2016), so only around $16 \%$ of total arable land could be covered with manure applied at a rate of $35 \mathrm{t} \mathrm{ha}^{-1} \mathrm{a}^{-1}$ which would lead to an SOC increase of $0.30 \mathrm{Tg} \mathrm{C} \mathrm{a}{ }^{-1}$. If this manure is already being applied to soils, there would be no net gain at the country level.

DDC has a low sensitivity of SOC changes to modification of $\mathrm{pH}$ by one unit, and $\mathrm{BD}$, clay content and FC by $10 \%$ which suggests that model predictions are not sensitive to any small input uncertainties at this site. DDC is a powerful tool for examining alternate hypothesis of discrepancies between modelled and measured values. The simulation results show consistently good fit to the measurements over the different treatments, which means the model is suitable to test different mitigation options for test sites.

Acknowledgements We thank the Lawes Agricultural Trust and Rothamsted Research for data from the e-RA database. The Rothamsted Long-term Experiments National Capability (LTENCG) is supported by the UK Biotechnology and Biological Sciences Research Council and the Lawes Agricultural Trust. The work was supported by Bangabandhu Fellowship on Science and ICT project, Ministry of Science and Technology, People's Republic of Bangladesh.

Open Access This article is distributed under the terms of the Creative Commons Attribution 4.0 International License (http:// creativecommons.org/licenses/by/4.0/), which permits unrestricted use, distribution, and reproduction in any medium, provided you give appropriate credit to the original author(s) and the source, provide a link to the Creative Commons license, and indicate if changes were made.

\section{References}

Alexander P, Paustian K, Smith P, Moran D (2015) The economics of soil $\mathrm{C}$ sequestration and agricultural emissions abatement. SOIL 1(1):331-339

Avery BW (1980) Soil classification for England and Wales [higher categories]. Technical Monograph 14, Soil Survey of England and Wales, Harpenden, UK

Avery BW, Bullock P (1969) The soils of Broadbalk: morphology and classification of Broadbalk soils. Rothamsted Experimental Station Report for 1968 (part 2), pp 63-81

BEIS (2015) 2015 UK greenhouse gas emissions. https://www. gov.uk/government/uploads/system/uploads/attachment_
data/file/589602/2015_Final_Emissions_Statistics_one_ page_summary.pdf

Chmielewski FM, Potts JM (1995) The relationship between crop yields from an experiment in southern England and long-term climate variations. Agric For Meteorol 73:43-66

Clark IM, Buchkina N, Jhurreea D, Goulding KW, Hirsch PR (2012) Impacts of nitrogen application rates on the activity and diversity of denitrifying bacteria in the Broadbalk wheat experiment. Philos Trans R Soc Lond B Biol Sci 367:1235-1244

Del Grosso SJ, Parton WJ, Mosier AR, Hartman MD, Brenner J, Ojima DS, Schimel D (2001) Simulated interaction of carbon dynamics and nitrogen trace gas fluxes using the DAYCENT model. In: Shaffer MJ, Ma L, Hansen S (eds) Modeling carbon and nitrogen dynamics for soil management. CRC Press, Boca Raton, pp 303-332

Del Grosso SJ, Parton WJ, Adler PR, Davis SC, Keough C, Marx E (2012) DayCent model simulations for estimating soil carbon dynamics and greenhouse gas fluxes from agricultural production systems. In: Liebig MA, Franzluebbers AJ, Follet RF (eds) Managing agricultural greenhouse gases. San Diego, CA, pp 241-250

Falloon PD, Smith P (2000) Modelling refractory soil organic matter. Biol Fertil Soils 30:388-398

Fitton N, Datta A, Smith K, Williams J, Hastings A, Kuhnert M, Topp CFE, Smith P (2014) Assessing the sensitivity of modelled estimates of $\mathrm{N}_{2} \mathrm{O}$ emissions and yield to input uncertainty at a UK cropland experimental site using the DailyDayCent model. Nutr Cycl Agroecosyst 99:119-133

Glendining MJ, Powlson DS, Poulton PR, Bradbury NJ, Palazzo D, Li X (1996) The effects of long-term applications of inorganic nitrogen fertilizer on soil nitrogen in the Broadbalk Wheat Experiment. J Agric Sci 127:347-363

Jenkinson DS, Andrew SPS, Lynch JM, Goss MJ, Tinker PB (1990) The turnover of organic carbon and nitrogen in soil [and discussion]. Philos Trans R Soc Biol Sci 329:361-368

Jenkinson DS, Harkness DD, Vance ED, Adams DE, Harrison AF (1992) Calculating net primary production and annual input of organic matter to soil from the amount and radiocarbon content of soil organic matter. Soil Biol Biochem 24:295-308

Johnston AE, Garner HV (1969) Broadbalk: historical introduction, Rothamsted experimental station report for 1968 . Part 2:12-25

Lal R (2013) Intensive agriculture and the soil carbon pool. J Crop Improv 27:735-751

Macdonald AJ, Powlson DS, Poulton PR, Watts CW, Clark IM, Storkey J, Hawkins NJ, Glendining MJ, Goulding KWT, McGrath SP (2015) The Rothamsted long-term experiments. Asp Appl Biol 128:1-10

Moss SR, Storkey J, Cussans JW, Perryman SAM, Hewitt MV (2004) The Broadbalk long-term experiment at Rothamsted: what has it told us about weeds? Weed Sci 52:864-873

Oliveira D, Williams S, Cerri CE, Paustian K (2017) Predicting soil $\mathrm{C}$ changes over sugarcane expansion in Brazil using the DayCent model. GCB Bioenergy 9:1436-1446

Parton WJ (1996) The CENTURY model. In. In: Powlson DS, Smith P, Smith JU (eds) Evaluation of soil organic matter models using existing long-term datasets NATO ASI 
Series I: global environmental change, vol 38. Springer, Berlin, pp 283-291

Parton WJ, Rasmussen PE (1994) Long-term effects of crop management in wheat-fallow: II. CENTURY model simulations. Soil Sci Soc Am J 58:530-536

Parton WJ, Schimel DS, Cole CV, Ojima DS (1987) Analysis of factors controlling soil organic matter levels in Great Plains grasslands. Soil Sci Soc Am J 51(5):1173-1179

Parton WJ, Hartman M, Ojima D, Schimel D (1998) DAYCENT and its land surface submodel: description and testing. Glob Plan Change 19:35-48

Paustian K, Andrén O, Janzen HH, Lal R, Smith P, Tian G, Tiessen H, Noordwijk MV, Woomer PL (1997) Agricultural soils as a sink to mitigate $\mathrm{CO}_{2}$ emissions. Soil Use Manag 13:230-244

Powlson DS (1996) Why evaluate soil organic matter models? In: Powlson DS, Smith P, Smith JU (eds) Evaluation of soil organic matter models using existing long-term datasets NATO ASI Series I: global environmental change, vol 38. Springer, Berlin, pp 3-11

Powlson DS, Johnston AE, Jenkinson DS (1986) The nitrogen cycle in the Broadbalk Wheat Experiment: recovery and losses of $15 \mathrm{~N}$-labelled fertilizer applied in spring and inputs of nitrogen from the atmosphere. J Agric Sci 107:591-609

Powlson DS, Bhogal A, Chambers BJ, Coleman K, Macdonald AJ, Goulding KWT, Whitmore AP (2012) The potential to increase soil carbon stocks through reduced tillage or organic material additions in England and Wales: a case study. Agric Ecosyst Environ 146:23-33

Powlson DS, MacDonald AJ, Poulton PR (2014) The continuing value of long-term field experiments: insights for achieving food security and environmental integrity. In: Dent D (ed) Soil as World Heritage, part II. Springer, Berlin, pp 131-157

Rothamsted Research (2006) Guide to the Classical and other long-term experiments, datasets and sample archive. Lawes Agricultural Trust Co. Ltd, Harpenden, UK. https:// doi.org/10.23637/rothamsted-long-term-experimentsguide-2006

Senapati N, Chabbi A, Giostri AF, Yeluripati JB, Smith P (2016) Modelling nitrous oxide emissions from mown-grass and grain-cropping systems: testing and sensitivity analysis of DailyDayCent using high frequency measurements. Sci Total Environ 572:955-977

Smith P (2004) Carbon sequestration in croplands: the potential in Europe and the global context. Eur J Agron 20:229-236

Smith J, Smith P (2007) Environmental modelling: an introduction. Oxford University Press, New York

Smith K, Williams A (2016) Production and management of cattle manure in the UK and implications for land application practice. Soil Use Manag 32:73-82
Smith JU, Smith P, Addiscott TM (1996) Quantitative methods to evaluate and compare soil organic matter (SOM) models. In: Powlson DS, Smith P, Smith JU (eds) Evaluation of soil organic matter models using existing long-term datasets NATO ASI Series I: global environmental change, vol 38. Springer, Berlin, pp 181-199

Smith P, Smith JU, Powlson DS, McGill WB, Arah JRM, Chertov OG, Coleman K, Franko U, Frolking S, Jenkinson DS, Jensen LS, Kelly RH, Klein-Gunnewiek H, Komarov A, Li C, Molina JAE, Mueller T, Parton WJ, Thornley JHM, Whitmore AP (1997) A comparison of the performance of nine soil organic matter models using seven longterm experimental datasets. Geoderma 81:153-225

Smith P, Powlson DS, Smith JU, Falloon PD, Coleman K (2000) Meeting Europe's climate change commitments: quantitative estimates of the potential for carbon mitigation by agriculture. Glob Change Biol 6:525-539

Smith P, Martino D, Cai Z, Gwary D, Janzen HH, Kumar P, McCarl B, Ogle S, O’Mara F, Rice C, Scholes RJ, Sirotenko O, Howden M, McAllister T, Pan G, Romanenkov V, Rose S, Schneider U, Towprayoon S (2007) Agriculture. In: Metz B, Davidson OR, Bosch PR, Dave R, Meyer LA (eds) Chapter 8 of climate change 2007: mitigation. Contribution of working group III to the fourth assessment report of the intergovernmental panel on climate change. Cambridge University Press, Cambridge, pp 497-540

Smith P, Martino D, Cai Z, Gwary D, Janzen H, Kumar P, McCarl B, Ogle S, O’Mara F, Rice C, Scholes B, Sirotenko O, Howden M, McAllister T, Pan G, Romanenkov V, Schneider U, Towprayoon S, Wattenbach M, Smith J (2008) Greenhouse gas mitigation in agriculture. Philos Trans R Soc Lond B Biol Sci 363:789-813

Smith P, Bustamante M, Ahammad H, Clark H, Dong H, Elsiddig EA, Haberl H, Harper R, House J, Jafari M, Masera O, Mbow C, Ravindranath NH, Rice CW, Robledo Abad C, Romanovskaya A, Sperling F, Tubiello F (2014) Agriculture, forestry and other land use (AFOLU). In: Edenhofer O, Pichs-Madruga R, Sokona Y, Farahani E, Kadner S, Seyboth K, Adler A, Baum I, Brunner S, Eickemeier P, Kriemann B, Savolainen J, Schlömer S, von Stechow C, Zwickel T, Minx JC (eds) Climate change 2014: mitigation of climate change. Contribution of working group III to the fifth assessment report of the intergovernmental panel on climate change. Cambridge University Press, Cambridge, pp 811-922

Thorne GN, Darby RJ, Day W, Lane PW, Welbank PJ, Widdowson FV (1988) Variation between years in growth and nutrient uptake after anthesis of winter wheat on Broadbalk field at Rothamsted, 1969-84. J Agric Sci 110:543-559 